\title{
Chemo/immuno/hormone Therapy Regimen
}

National Cancer Institute

\section{Source}

National Cancer Institute. Chemo/immuno/hormone Therapy Regimen. NCI Thesaurus.

Code C62634.

Any regimen that can be used for the treatment of cancer and non-neoplastic disease. 